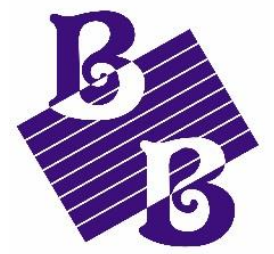

BioBacta

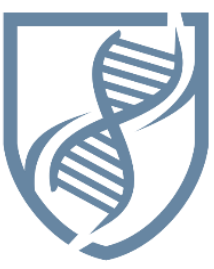

Journal of Bioscience and Applied Research

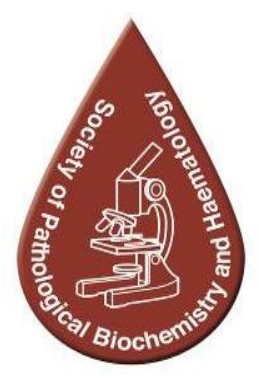

www.jbaar.org

\title{
Assessment of environmental and pollution level in water and insect's fauna of freshwater habitat
}

\author{
${ }^{1,2}$ Masood, M F; ${ }^{3}$ A. S. Al-Nasser; ${ }^{1,4}$ Salama A. S.; ${ }^{4}$ EH Radwan; and ${ }^{5}$ KH Radwan \\ 1 Biology Department, Faculty of Science, Jazan University, KSA \\ 2 Faculty of Science, Al-Azhar University (Asuit-Egypt) \\ 3 Biology Department, Faculty of Science, University of Jeddah, KSA \\ *4 Zoology Department, Faculty of Science, Damanhour University, Egypt. \\ 5Agricultural Genetic Engineering Research Institute (AGERI), Cairo, Egypt \\ *Corresponding author: dr_eman_hashem@yahoo.com; M_F_Masood@yahoo.com
}

DOI: 10.21608/jbaar.2018.155992

\begin{abstract}
The environmental problems have raised the interest for bio-indicators able to reflect their environment. Among these life forms, the insects may contribute to a viable evaluation of the sustainability degrees. The Egyptian Mediterranean coast exhibits six lakes which are situated along the Nile Delta coast; Northern Delta lakes; Manzala, Borollus, Edku, and Mariut, and to the east of the Suez Canal, Port-Fouad and Bardawil. The current study aimed to evaluate different heavy metals in aquatic insects Ochthebius (Asiobates) rugulosus Wollaston 1857, taken from Lake Manzala, and to estimate their effect on the oxidative stress markers to employ insects as sensitive bio-monitors for environmental pollution. A lot of fluctuations were observed affected by the poor connection of the water body of the lake Manzala. The mean level concentrations of $\mathrm{Pb}, \mathrm{Cd}, \mathrm{Cu}$ and $\mathrm{Zn}$ in loc.\#1, whereas; 0.98, 3.02, 0.35 and $1.99 \mu \mathrm{g} / \mathrm{l}$; respectively with the arrangement of $\mathrm{Cu}<\mathrm{Pb}<\mathrm{Zn}<\mathrm{Cd}$ in location \#1 whereas it was reported as 1.8, 3.64, 1.32 and $2.2 \mu \mathrm{g} / \mathrm{l}$ in location\#2, giving the arrangement of $\mathrm{Pb}<\mathrm{Cu}<\mathrm{Zn}$ $<\mathrm{Cd}$ in loc.\#2. The mean concentration level of $\mathrm{Pb}$ in both locations was less than that recommended by the USEPA, $2005(2.5-65 \mu \mathrm{g} / \mathrm{l}), \mathrm{Cd}$ in the present study was higher than that of the water quality criteria; $(0.2-2 \mu \mathrm{g} / \mathrm{l})$ recommended by USEPA, 2005 in both locations in Lake Manzala. The $\mathrm{pH}$ values of water were alkaline throughout the lake. It is concluded from the obtained data that the southeastern region showed worse quality parameters. The $\mathrm{pH}$ of the water lake (loc.1; 7.7), (loc.\#2; 7.3) was found to be slightly alkaline throughout the spring (March-May, 2018). The $\mathrm{pH}$ was within the prescribed limits (6.5-9) of USEPA, 2005. In the current study, $\mathrm{Cu}$ and $\mathrm{Zn}$ concentration in Ochthebius (Asiobates) rugulosus Wollaston 1857, in Lake Manzala ranged from (0.2$0.1 \mu \mathrm{g} / \mathrm{g}, 0.07-0.09 \mu \mathrm{g} / \mathrm{g})$. The mean concentration of heavy metal was significantly $(\mathrm{p}<0.05)$ different in water samples collected from Lake Manzala, Spring; 2018. The arrangement of elements in the insect tissue was as; $\mathrm{Cu}$ $>\mathrm{Pb}>\mathrm{Zn}>\mathrm{Cd}$. There was a significant increase in the mean concentrations level of ALT activity in insects from loc. \#2; 42.6 (U/mg protein), while it was 37 (U/mg protein) in that of loc.\#1. The mean concentration level of
\end{abstract}


AST activity in insects from loc.\#1 was 50.8 (U/mg protein), while it was 59 (U/mg protein) in that of loc.\#2. A significant decrease in GPx activity in insects from loc.\#2 was found as, 68.74 (mU/mg protein), while it was $77.4 \mathrm{mU} / \mathrm{mg}$ protein in that of loc.\#1. The results of the present study showed that there was a significant decrease in GPx activity in samples collected from loc.\#2 compared with that of loc.\#1 telling that insects in loc.\#2 are under stress of sewage pollution (Bahr El Baqur) drain. The $\mathrm{Pb}$ in insect tissues in loc.\#1 is positively correlated with $\mathrm{Zn}$ in insect tissues, TP, MDA, and GPx as $\mathrm{r}=0.693, \mathrm{r}=0.854, \mathrm{r}=0.873$, and $\mathrm{r}=644$; respectively. $\mathrm{Cd}$ in insect tissues is positively correlated with AST, TP, MDA and GPx as r=0.870, r=0.690, r=0.666 and r=0.737; respectively. $\mathrm{Cu}$ in insect tissues is negatively correlated with AST as $\mathrm{r}=-0.739 . \mathrm{Zn}$ in insect tissues is positively correlated with TP, MDA, and GPx as $\mathrm{r}=0.742, \mathrm{r}=0.810, \mathrm{r}=0.951^{*}$; respectively. TP is highly positively correlated with MDA and GPx as $r=0.983^{*}$, and $r=0.840^{*}$; respectively whereas, MDA is highly positively correlated with $\mathrm{GPx}$ as $\mathrm{r}=0.882 *$. In loc.\#2, $\mathrm{Pb}$ in insect tissues is negatively correlated with $\mathrm{Cu}$ in insect tissues, TP, MDA and GPx as $\mathrm{r}=-0.716, \mathrm{r}=-0.916^{*}, \mathrm{r}=-0.878^{*}$ and $\mathrm{r}=-0.704$; respectively. $\mathrm{Cd}$ in insect tissues is negatively correlated with MDA as $\mathrm{r}=-0.655$. $\mathrm{Cu}$ in insect tissues is positively correlated with TP and GPx as $\mathrm{r}=0.806$ and $\mathrm{r}=0.658$; respectively. $\mathrm{Zn}$ in insect tissues is negatively correlated with AST as $\mathrm{r}=-0.813$.

Key words: Ecology- environment- fauna- pollution- lakes- beetles - Manzala.

\section{Introduction}

Manzala is the largest coastal lake in Egypt which is shallow brackish extending between the Damietta Nile River branch and the Suez Canal with a maximum length of $50 \mathrm{~km}$ along the Mediterranean sea (Ahmed et al., 2009). Wastewater effluents are flowing into Manzala Lake from nine major drains and canals. Fraskur, AlSarw, Baghous, Abu Garida, Bahr El Baqur, are the most important of them. Manzala Lake is suffering environmental changes where a human activity such as the construction of fish farms, roads, and agricultural purposes have changed the lake to a semi-closed subbasin (Elmorsi et al., 2017). The $\mathrm{pH}$ of water samples was within the water criteria limits (6.5-9) (GAFRD, 2015). The $\mathrm{pH}$ values were generally high in northern sites influenced by the inflows from the seawater inlets (Abdo, 2004).

Aquatic Coleoptera constitutes a significant part of freshwater habitats. Approximately 25 families in three of four suborders of Coleoptera are typically aquatic in some of their life stages (Balke, 2005). Among these are the minute moss beetles of the family Hydraenidae. These are small beetles, 1-3 mm long (Jäch, 1995). Aquatic insects might be adversely influenced by heavy metals in the environment. The toxicity is grandly a function of the water chemistry and sediment composition in the surface water system (Mahler and Van Metre, 2006). The insects are responsible for numerous processes in the ecosystem and their loss can have negative impacts on entire communities (Gray et al., 1999; Nicholsa et al., 2007). The toxicity of metals is the capacity of a metal to bring about undesirable impacts on aquatic organisms
(Rasmussen and Sorensen, 2000). The poisonous quality increments when the medium ends up acidic (Mukhopadhyay and Hashim, 2011). Heavy metals are brought into aquatic systems, rivers, lakes through dumping wastes and domestic effluents (Al-Yousuf and El Shahawi, 2000; Radwan et al., 2012; Radwan et al., 2014; Radwan, 2016; Radwan et al., 2016; Radwan et al., 2017; Radwan et al., 2018).

Substantial metals defile the earth due to their non-degradable nature (Ayanabenro and Babalola, 2017), the wastewater goes into the soil (Easa and Abou Rayan, 2010). Metalloids have caused harm to the biological community (Gaur et al., 2014). Agrarian spillovers contain contaminations from herbicides and pesticides, which effectively affect the waterway and the general population utilizing it (Dakkak, 2016). Water contamination is the tainting of regular water bodies by physical, compound pathogenic, or microbial substances (Chaturvedi et al., 2013; Bahnasawy and Khidr, 2011). It has been proposed that water contamination is the basic overall reason for some sicknesses (Sa'eed and Mahmoud, 2014; Safari et al., 2014).

The impacts of heavy metals on different insects revealed, growth inhibition, reduced reproduction, developmental abnormalities, and decreased hatchability (Sidanchandra and Crane, 2000; Bijita et al., 2014). The Egyptian Mediterranean coast exhibits six lakes or lagoons which are situated along the Nile Delta coast; Northern Delta lakes Manzala, Borollus, Edku, and Mariut, and to the east of the Suez Canal, Port-Fouad and Bardawil (Mehanna, 2009). 
The contamination sources occur due to anthropogenic development. Since lakes are basic sinks for a few toxic substances gotten from their watershed, the lake can give rich information on the lake's overwhelming metal tainting and additionally on natural changes in the including catchments (Stephane et al., 2004; Thevenon et al., 2011). Metals apply their poisonous quality in living animals by different diverse systems, especially their intrusion in oxidative biochemical reactions through the advancement of receptive oxygen species (Goyer and Clarkson, 2001; Viarengo, 2003).

The ecological issues have raised the enthusiasm for bio-pointers ready to mirror their condition. Among these living things, the creepy crawlies may add to a reasonable assessment of the maintainability degree (Tylianakis et al., 2004; Lopes and Vasconcelos, 2008). The resilience of oceanic living beings to overwhelming metals has been illuminated by the metallo-thionein arrangement in various amphibian creatures (Bisthoven and Janssens, 1998). The water scrounger creepy crawlies are known among entomologists particularly they are frequently bounteous in many sorts of waters, possess waterways and distinctive environments (Hansen, 1999; Short and Heabuer, 2006). Various bugs are used for biosign because as they are polyphagous predators (Crowson, 1981).

The sources of ROS generation incorporate progress metals (Klaunig and Kamendulis, 2004). Superoxide anion is a type of responsive animal varieties (Miller et al., 1990). Heavy metal particles, for example, copper, and lead, can incite the age of responsive radicals. The cancer prevention agent parameters, for example, glutathione peroxidase and lipid peroxidation are utilized as biomarkers in an assortment of living beings (Cheung and Zheng, 2001). The most as often as possible archived and soonest result of the substantial metal poisonous quality in bug's cells is the overproduction of ROS (Shahid et al., 2014). MDA is considered the most mutagenic result of lipid peroxidation. MDA has been broadly utilized for a long time as an appropriate biomarker for lipid peroxidation, it is a standout amongst the most well-known and solid markers that decide oxidative worry in clinical circumstances (Giera and Ioan-Facsinay, 2012). At the point when oxidative pressure happens, cells attempt to adjust the oxidant impacts by an enactment of qualities encoding cautious catalysts factors, and basic proteins (Dalton and Sbertzer, 1999). Oxidation of methionine deposits of proteins causes conformational changes, protein unfurling, and corruption (Lyras and Caims, 1997).

The presence of contaminants in the aquatic environment poses significant toxicological risks to many organisms and finds its way to the food chain, threatening the ecological balance and the biodiversity of nature (Dar et al., 2014). Most of the chemicals used on land enter the aquatic environment via wastewater from agricultural and domestic sources including municipal sewage treatment plants (Ohe et al., 2004). Enzymatic antioxidant defenses involve superoxide dismutase, glutathione peroxidase, and catalase (Valko and Leibfritz, 2007). The glutathione peroxidase system contains many components, including the enzymes glutathione peroxidase (Schafer and Buetlner, 2001). The ROS are removed in cells by antioxidant systems (Cadenas, 2004; Li and Kong, 2009). Several antioxidant responses, including oxidative stress biomarkers and antioxidant enzyme activities, are utilized in environmental risk assessment (Song et al., 2006). Amino transferases are enzymes that intermediate the transfer of an amino group from the amino donor to the acceptor for chiral amino acid or amine synthesis (Hollmann and Arends, 2011). The adjustments in protein are essential to demonstrate the defenselessness of organ systems to contaminations by changing their capacity (Fahmy, 2012). Tissue protein content has been recommended as an indicator of xenobiotic-induced stress in aquatic organisms (Singh and Sharma, 1998). The current study aimed to evaluate different heavy metals in aquatic insects taken from Lake Manzala. Estimate their effect on oxidative stress markers to estimate the probability of employing insects as sensitive monitors for environmental contaminates. 


\section{Material and methods}

The aquatic insect in the present study is the aquatic beetle; Ochthebius (Asiobates) rugulosus.

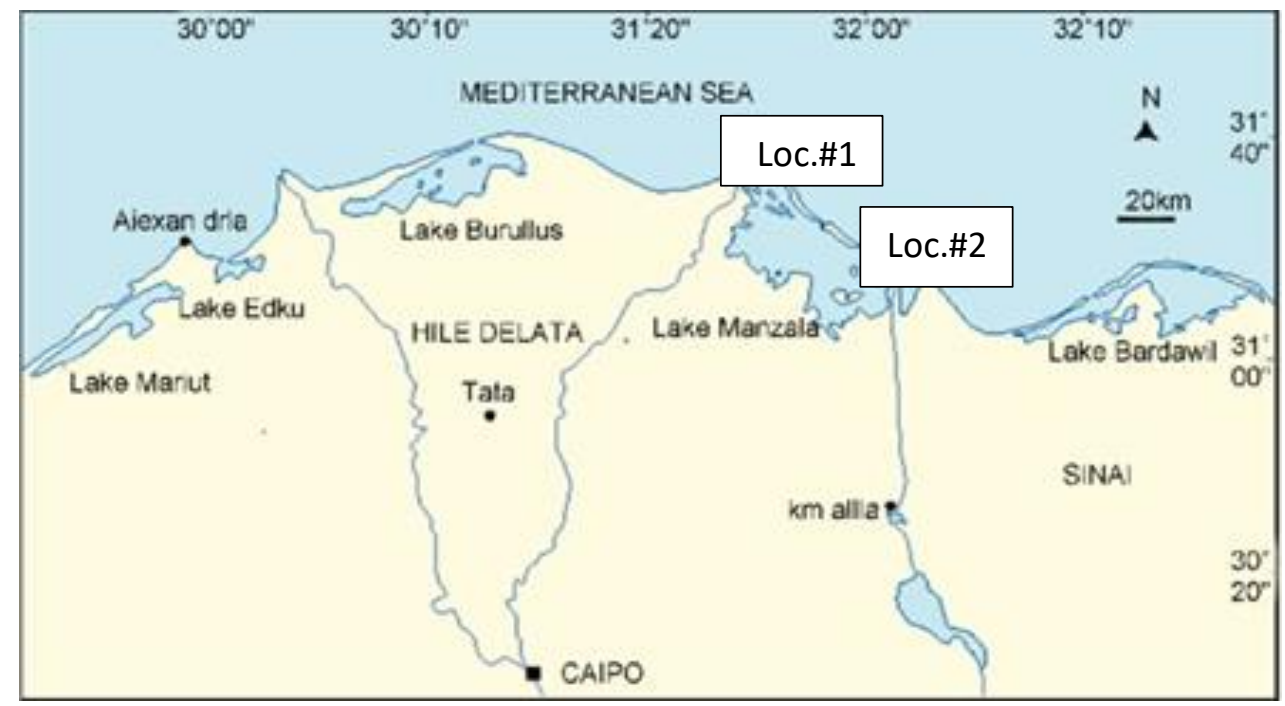

Fig. (1): Map of Manzala Lake (loc.\#1; west of the lake and loc.\#2; east of the lake)

Beetles and water were sampled from Lake Manzala in Spring (March-May, 2018); (the collection is biweek) location \#1 and \#2 (Fig. 1). This area is occasionally affected by the seawater entering the lake. Samples of the water beetle, each consisted, of 20 /time/location were collected from the studied Lake Manzala from each location/5 times replicates. Insects were then transferred to the laboratory within two hours where sorting. Sorted insects were washed in running water to remove any debris. Sorted insects were then kept at $-20{ }^{\circ} \mathrm{C}$ until processing. Water samples were filtered in the field using a polypropylene syringe fitted with a $0.45 \mu \mathrm{m}$ Millipore acetate fitter. Concentrations of heavy metals (lead, cadmium, copper, zinc) were measured in filtered lakes water according to (Riley and Taylor, 1968) using graphite furnace atomic absorption spectroscopy (Berkin- Elmer model 2380). The concentration level $(\mu \mathrm{g} / \mathrm{g}$ insect tissues) of; lead and cadmium, copper, zinc were determined in dry insect samples (five replicates collected from the two locations, lake Manzala according to Loring and Rantala (1992).

The $\mathrm{pH}$ and alkalinity of the lake water were measured by standard methods for the analysis of natural and treated wastewater described by the American Public Health Association (1975). The water of each location was analyzed to determine the chemical composition at the beginning of the study and was conducted with insect sampling. Five random water samples were collected from each sampling location about $20 \mathrm{~cm}$ below the water surface to avoid floating matter. Determination of Aspartate aminotransferase and Alanine aminotransferase activity was done according to (Tietz, 1976). Determination of Malondialdehyde (MDA) concentration was according to (Ohkawa et al., 1979). Determination of glutathione peroxidase activity was according to (Paglia and Valentine, 1967) and determination of the total protein content was according to Lowry et al. (1951). Statistical analysis: Data were fed to the computer and analyzed using IBM SPSS software package version 20.0. Data were fed to the computer and analyzed using IBM SPSS software package version 20.0. (Armonk, NY: IBM Corp). The Kolmogorov- Smirnov, Shapiro, and D' agstino tests were used to verify the normality of distribution of variables, Student t-test was used to compare two groups for normally distributed quantitative variables. Pearson coefficient was used to correlate between quantitative variables. Significance of the obtained results was judged at the 5\% level (Bauley 1981; Lesilie et al., 1991; Puri, 2002)

\section{Results:}

The obtained data from table (1), fig. (2) showed that the mean level concentrations of $\mathrm{Pb}, \mathrm{Cd}, \mathrm{Cu}$, and $\mathrm{Zn}$ in loc.\#1, whereas; 0.98, 3.02, 0.35, and $1.99 \mu \mathrm{g} / \mathrm{l}$; respectively with the arrangement of $\mathrm{Cu}<\mathrm{Pb}<\mathrm{Zn}<$ $\mathrm{Cd}$ in location \#1 whereas it was reported as 1.8, 3.64, 
1.32 and $2.2 \mu \mathrm{g} / \mathrm{l}$ in location\#2, giving the arrangement of $\mathrm{Pb}<\mathrm{Cu}<\mathrm{Zn}<\mathrm{Cd}$ in loc.\#2. The mean concentration level of $\mathrm{Pb}$ in both locations was less than that recommended by the USEPA, 2005 (2.5$65 \mu \mathrm{g} / \mathrm{l}), \mathrm{Cd}$ in the present study was higher than that of the water quality criteria; $(0.2-2 \mu \mathrm{g} / \mathrm{l})$ recommended by USEPA, 2005 in both locations in Lake Manzala.

The parameters of water samples collected from the two locations Lake Manzala compared with that of the United States Environmental Protection Agency USEPA (2005). The mean concentration level of $\mathrm{Cu}$ and $\mathrm{Zn}$ in the present study showed a low level of concentration than that recommended by USEPA, $2005(9-13 \mu \mathrm{g} / \mathrm{l})$ and $(120 \mu \mathrm{g} / \mathrm{l})$; respectively in both locations of Lake Manzala during spring (March-May 2018). The data cited in a table (1) indicated that the mean concentration level of $\mathrm{Pb}, \mathrm{Cu}, \mathrm{Zn}$ in lake Manzala were less than the standard criteria recommended by USEPA, 2005, only Cd was reported in a higher concentration level than the criteria recommended by USEPA, 2005. The data represented in table (1) showed that the mean concentration of heavy metal was significantly $(p<0.05)$ different in water samples collected from Lake Manzala, Spring, 2018.

Table (1a, b): Trace metal concentrations $(\mu \mathrm{g} / \mathrm{L})$ in water samples from Lake Manzala in Spring (March-May, 2018):

\begin{tabular}{|l|l|l|l|l|}
\hline Table1,a & $\begin{array}{l}\text { Loc.\#1 } \\
\text { (West side of the lake) }\end{array}$ & t-test & $p$ & USEPA, 2005 (freshwater standard criteria) \\
\hline $\mathrm{Pb} \mu \mathrm{g} / \mathrm{l}($ Mean) & $0.98 \pm 0.5^{*}$ & $2.687^{*}$ & $0.028^{*}$ & $2.5-65$ \\
\hline $\mathrm{Cd} \mu \mathrm{g} / \mathrm{l}$ (Mean) & $3.02 \pm 1.9$ & 0.479 & $0.645^{*}$ & $0.25-2$ \\
\hline $\mathrm{Cu} \mu \mathrm{g} / \mathrm{l}$ (Mean) & $0.35 \pm 0.3^{*}$ & $3.017^{*}$ & $0.017^{*}$ & $9-13$ \\
\hline $\mathrm{Zn} \mu \mathrm{g} / \mathrm{l}$ (Mean) & $1.99 \pm 1.7$ & 0.190 & 0.854 & 120 \\
\hline
\end{tabular}

Data were expressed by using mean \pm S.D. Statistically significant: at $\mathrm{p}^{*} \leq 0.05$

\begin{tabular}{|l|l|l|l|l|}
\hline Table1,b & $\begin{array}{l}\text { Loc.\#2 } \\
\text { (East side of the lake) }\end{array}$ & t-test & P & USEPA, 2005 (freshwater standard criteria) \\
\hline $\mathrm{Pb} \mu \mathrm{g} / \mathrm{l}(\mathrm{Mean})$ & $1.8 \pm 0.5^{*}$ & $2.687^{*}$ & $0.028^{*}$ & $2.5-65$ \\
\hline $\mathrm{Cd} \mu \mathrm{g} / \mathrm{l}$ (Mean) & $3.64 \pm 2.2^{*}$ & 0.479 & 0.645 & $0.25-2$ \\
\hline $\mathrm{Cu} \mu \mathrm{g} / \mathrm{l}$ (Mean) & $1.32 \pm 0.7^{*}$ & $3.017^{*}$ & $0.017^{*}$ & $9-13$ \\
\hline $\mathrm{Zn} \mu \mathrm{g} / \mathrm{l}$ (Mean) & $2.2 \pm 1.7^{*}$ & & & 120 \\
\hline
\end{tabular}




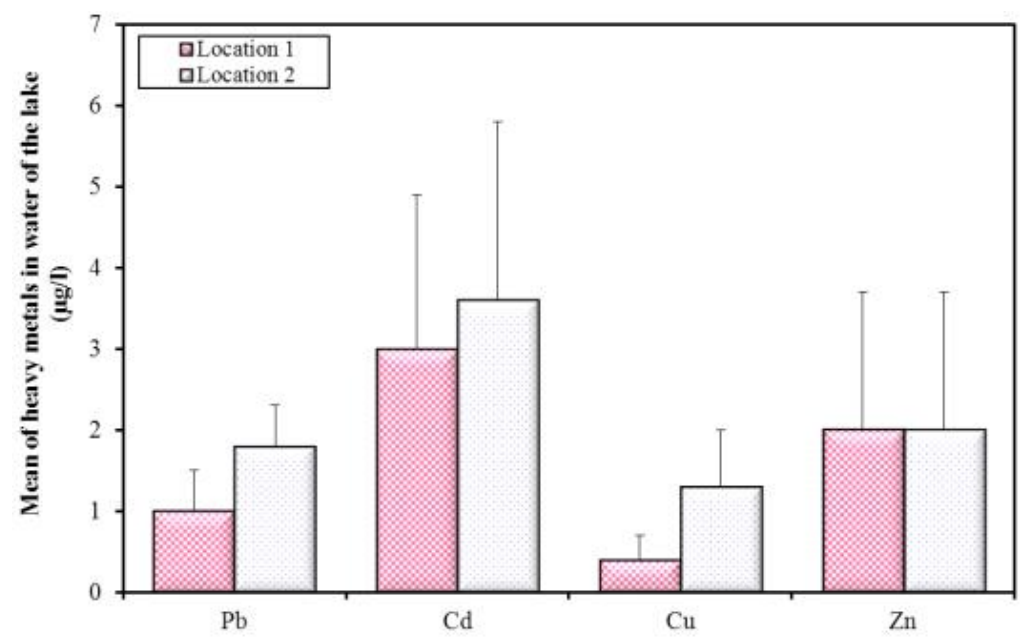

Fig.2: The mean concentration level of some heavy metals in Lake Manzala water in Spring, 2018.

Table (2), fig. (3) represents the $\mathrm{pH}$ value, the alkalinity, the obtained data showed that the mean value of $\mathrm{pH}$ in loc.\#1 was $7.7(\mathrm{mg} / \mathrm{L})$, whereas in loc.\#2 it was 7.3(mg/L).USEPA (2005), reported the $\mathrm{pH}$ concentration level in freshwater ranges between (6.5-9), giving the water lake is within that range and that water of lake Manzala is on the alkaline side.
There was a significant increase in alkalinity in loc.\#2 as $17.98(\mathrm{mg} / \mathrm{L})$, while that of loc.\#1 was $14.9(\mathrm{mg} / \mathrm{L})$ table (2) and that is less than the standards for USEPA (2005). The USEPA, 2005 criteria are (2000), the water of the lake is less than that recommended criteria.

Table (2): Physico-chemical characteristics of water collected from lake Manzala (loc.\#1 and loc.\#2):

\begin{tabular}{|c|c|c|c|c|c|}
\hline & Loc.\#1 & Loc.\#2 & t-test & P & $\begin{array}{l}\text { SEPA, 2005 } \\
\text { shwater criteri }\end{array}$ \\
\hline $\mathrm{pH}$ & $7.7 \pm 0.1^{*}$ & $7.3 \pm 0.2^{*}$ & $4.583^{*}$ & $0.002^{*}$ & $6.5-9$ \\
\hline Alk & $14.9 \pm 1.1^{*}$ & $17.98 \pm 0.3^{*}$ & $6.256^{*}$ & $0.002^{*}$ & 2000 \\
\hline
\end{tabular}

Data were expressed by using mean \pm S.E. Statistically significant at $\mathrm{p}^{*} \leq 0.05$ 

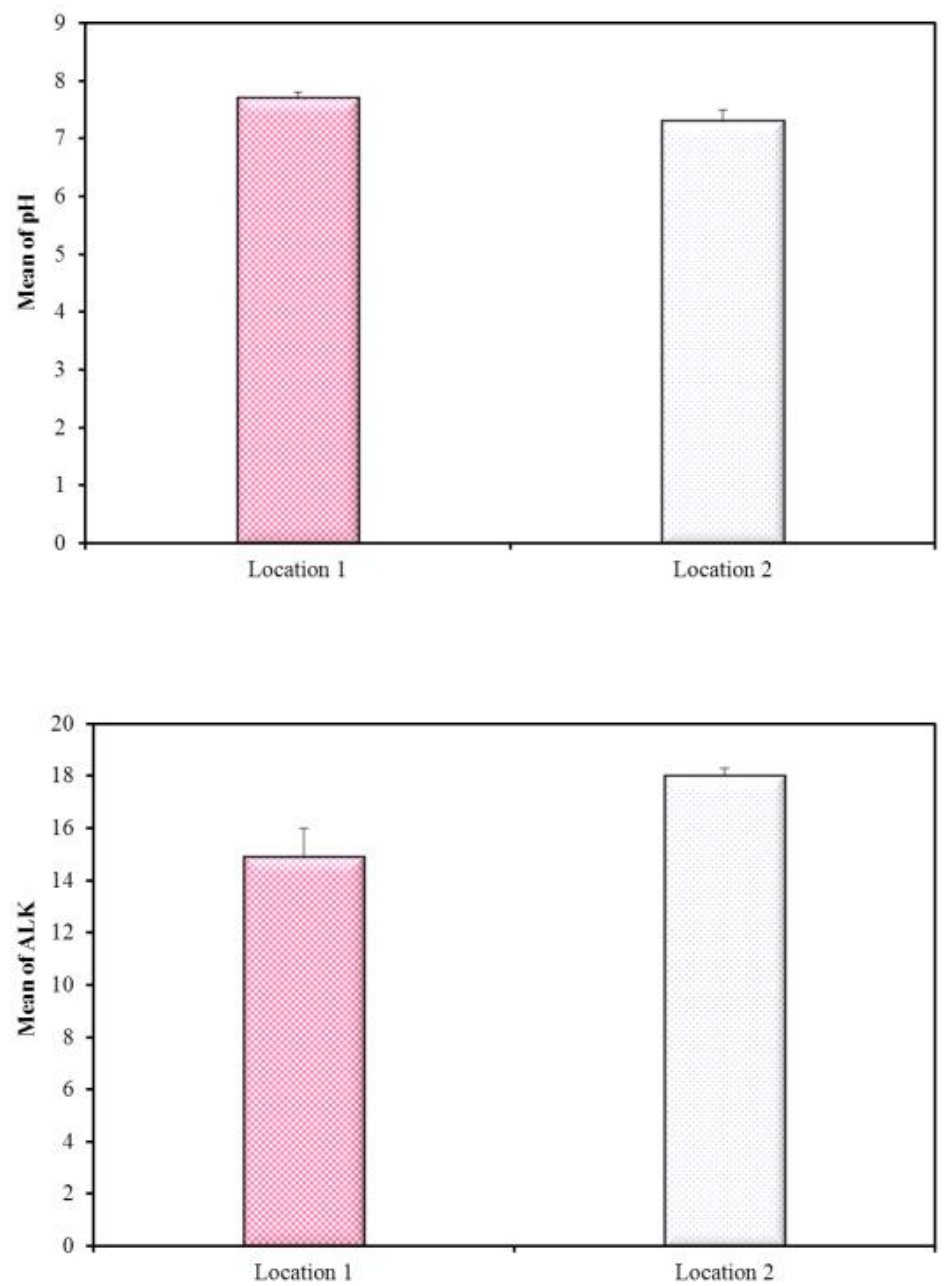

Fig. (3 a, b): Represents the pH and Alkalinity of the Lake Manzala water in Spring, 2018

Table (3): Heavy metals mean concentration levels in insects ( $\mu \mathrm{g} / \mathrm{g}$ dry weight) collected from Lake Manzala (Spring, 2018)

\begin{tabular}{|c|c|c|l|l|}
\hline & Loc.\#1 & loc.\#2 & \multicolumn{1}{|c|}{ t-test } & \multicolumn{1}{|c|}{} \\
\hline $\mathrm{Pb} \mu \mathrm{g} / \mathrm{g}$ & $0.06 \pm 0.01$ & $0.12 \pm 0.02$ & 1.713 & 0.125 \\
\hline $\mathrm{Cd} \mu \mathrm{g} / \mathrm{g}$ & $0.03 \pm 0.01$ & $0.03 \pm 0.01$ & 0.000 & 1.000 \\
\hline $\mathrm{Cu} \mu \mathrm{g} / \mathrm{g}$ & $0.20 \pm 0.30$ & $0.10 \pm 0.01$ & 0.664 & 0.543 \\
\hline $\mathrm{Zn} \mu \mathrm{g} / \mathrm{g}$ & $0.07 \pm 0.02$ & $0.09 \pm 0.03$ & 1.241 & 0.250 \\
\hline
\end{tabular}

Data were expressed by using mean \pm S.E. Statistically significant at $\mathrm{p}^{*} \leq 0.05$ 


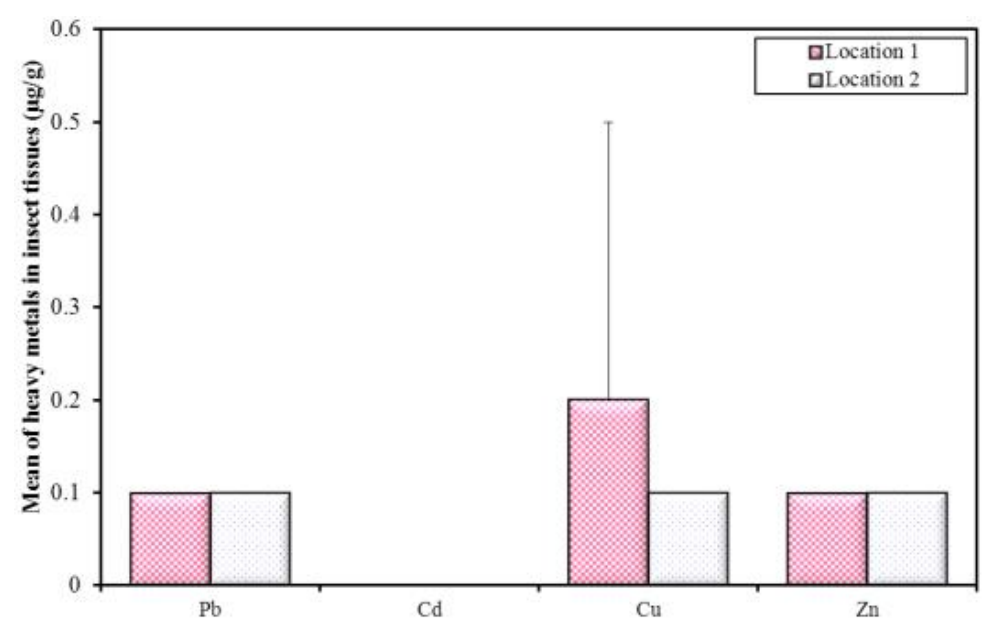

Fig. (4): Histogram represents the heavy metals mean concentration levels in insects collected from Lake Manzala in Spring, 2018.

The obtained data in table (3), fig (4) showed that the mean level concentrations of $\mathrm{Pb}, \mathrm{Cd}, \mathrm{Cu}, \mathrm{Zn}$ in insects' tissues which were collected from loc.\#1 was reported as; $0.06,0.03,0.20,0.07$ ( $\mu \mathrm{g} / \mathrm{g}$ dry weight) whereas, it was reported as; 0.12,0.03,0.10,0.09 $(\mu \mathrm{g} / \mathrm{g}$ dry weight); respectively, in loc.\#2. The data in table (3) showed a significant difference between the mean concentrations of $\mathrm{Pb}, \mathrm{Cu}, \mathrm{Zn}$ in insect tissues in the two locations Lake Manzala (spring, 2018). The results in the above-cited table found that $\mathrm{Cu}$ has the highest concentration level in the insect as $0.20(\mu \mathrm{g} / \mathrm{g}$ dry weight) in loc.\#1 in Lake Manzala then $\mathrm{Pb}$ in loc.\#2 as $0.12(\mu \mathrm{g} / \mathrm{g}$ dry weight) followed by $\mathrm{Zn}$ as 0.09 ( $\mu \mathrm{g} / \mathrm{g}$ dry weight) in loc.\#2. The arrangement of elements in the insect tissue was as; $\mathrm{Cu}>\mathrm{Pb}>\mathrm{Zn}>$ $\mathrm{Cd}$. The present data represented in table (3), fig. (4), showed that the mean concentration of heavy metal in the insect tissues was significantly $(\mathrm{p}<0.001)$ different in beetles collected from the two sites of Lake Manzala.

Table (4): The mean concentration of activity level of ALT, AST and the mean concentration levels of the total protein content in insects collected from Lake Manzala, Spring, 2018.

\begin{tabular}{|c|l|l|l|l|}
\hline & Loc.\#1 & Loc.\#2 & t-test & P \\
\hline ALT & $37 \pm 2.1^{*}$ & $42.6 \pm 1.8^{*}$ & $4.484^{*}$ & $0.002^{*}$ \\
\hline AST & & & & \\
(U/mg protein) & & $50.8 \pm 1.3^{*}$ & $12.362^{*}$ & $<0.001^{*}$ \\
& & & & \\
\hline T.P. (mg/g tissue) & $4.9 \pm 0.3^{*}$ & $4.02 \pm 0.4^{*}$ & $4.274^{*}$ & $0.003^{*}$ \\
& & & & \\
\hline
\end{tabular}

Data were expressed by using mean \pm S.E. Statistically significant at $\mathrm{p}^{*} \leq 0.05$ 

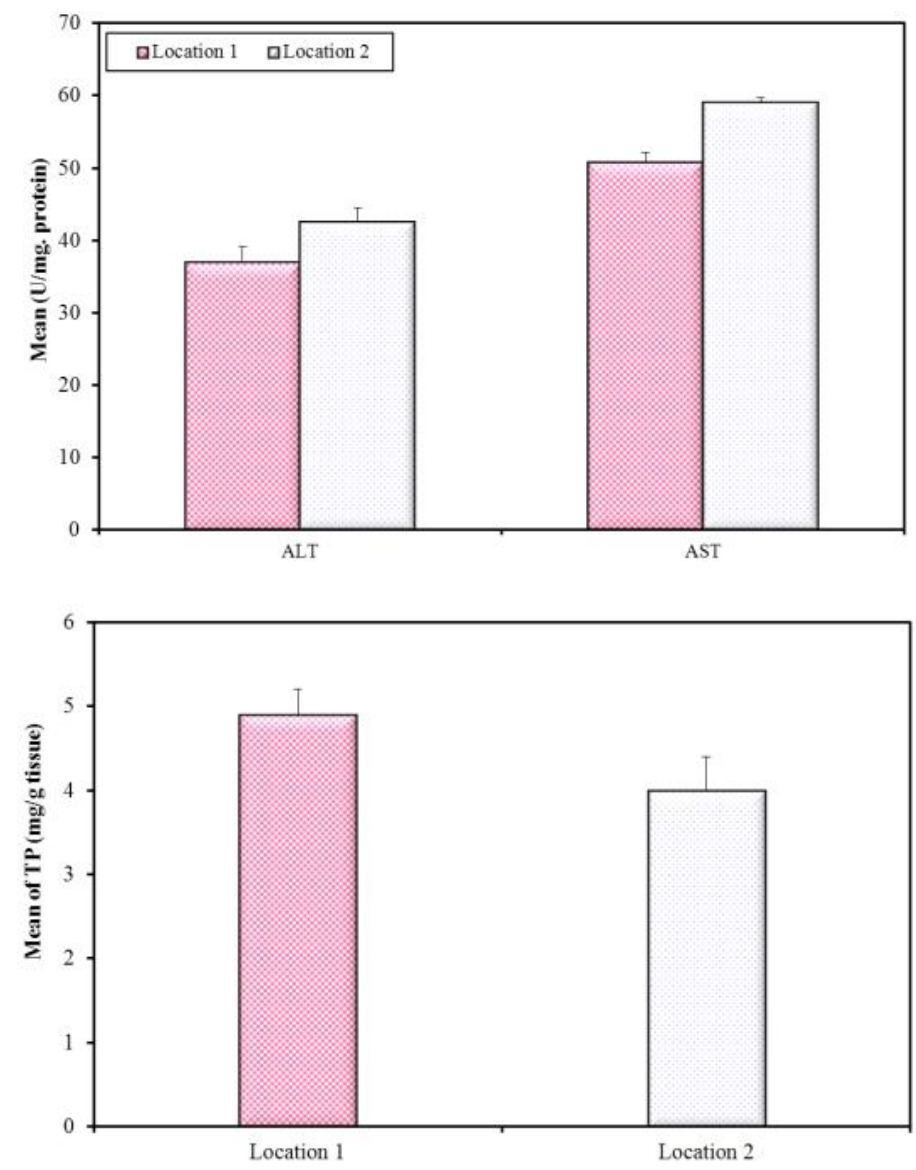

Fig. (5 a, b): Represents ALT, AST, T.P. collected from the insect in Lake Manzala, Spring, 2018

It is indicated from table (4), fig. (5), that there was a significant increase in the mean concentrations level of ALT activity in beetles in loc.\# 2; 42.6 (U/mg protein), while it was 37 (U/mg protein) in that of loc.\#1. The mean concentration level of AST activity in beetles in loc.\#1 was 50.8 (U/mg protein), while it was $59(\mathrm{U} / \mathrm{mg}$ protein) in that of loc.\#2. The present results showed that there was a significant increase in the AST activity in samples collected from loc.\#2 compared with that of loc.\#1. The data cited in table
(4) indicated a significant decrease of the mean concentration level of the total protein content in beetles in loc.\#2 compared with that of loc.\#1. The level of total protein content was 4.9 (mg/g tissue) in loc.\#1, while it was 4.02 (mg/g tissue) in that of loc.2. The mean concentration level of ALT and AST showed were high in insects collected from loc.\#2 and the total protein was high in insects collected from loc.\#1.

Table (5): Mean concentrations (mean \pm S.D.) of MDA, GPx activities of beetles from Lake Manzala (loc.\#1 and loc.\#2)

\begin{tabular}{|l|l|l|l|l|}
\hline & Loc.\#1 & Loc.\#2 & t-test & P \\
\hline MDA (n mol/mg tissue) & $14.02 \pm 0.4^{*}$ & $20.08 \pm 0.8^{*}$ & $15.112^{*}$ & $<0.001^{*}$ \\
& & & & \\
\hline GPx (mU/mg. protein) & $77.4 \pm 3.6$ & $68.74 \pm 2.0^{*}$ & $4.735^{*}$ & $0.001^{*}$ \\
& & & & \\
\hline
\end{tabular}

Data were expressed by using mean \pm S.E. Statistically significant at $\mathrm{p}^{*} \leq 0.05$ 

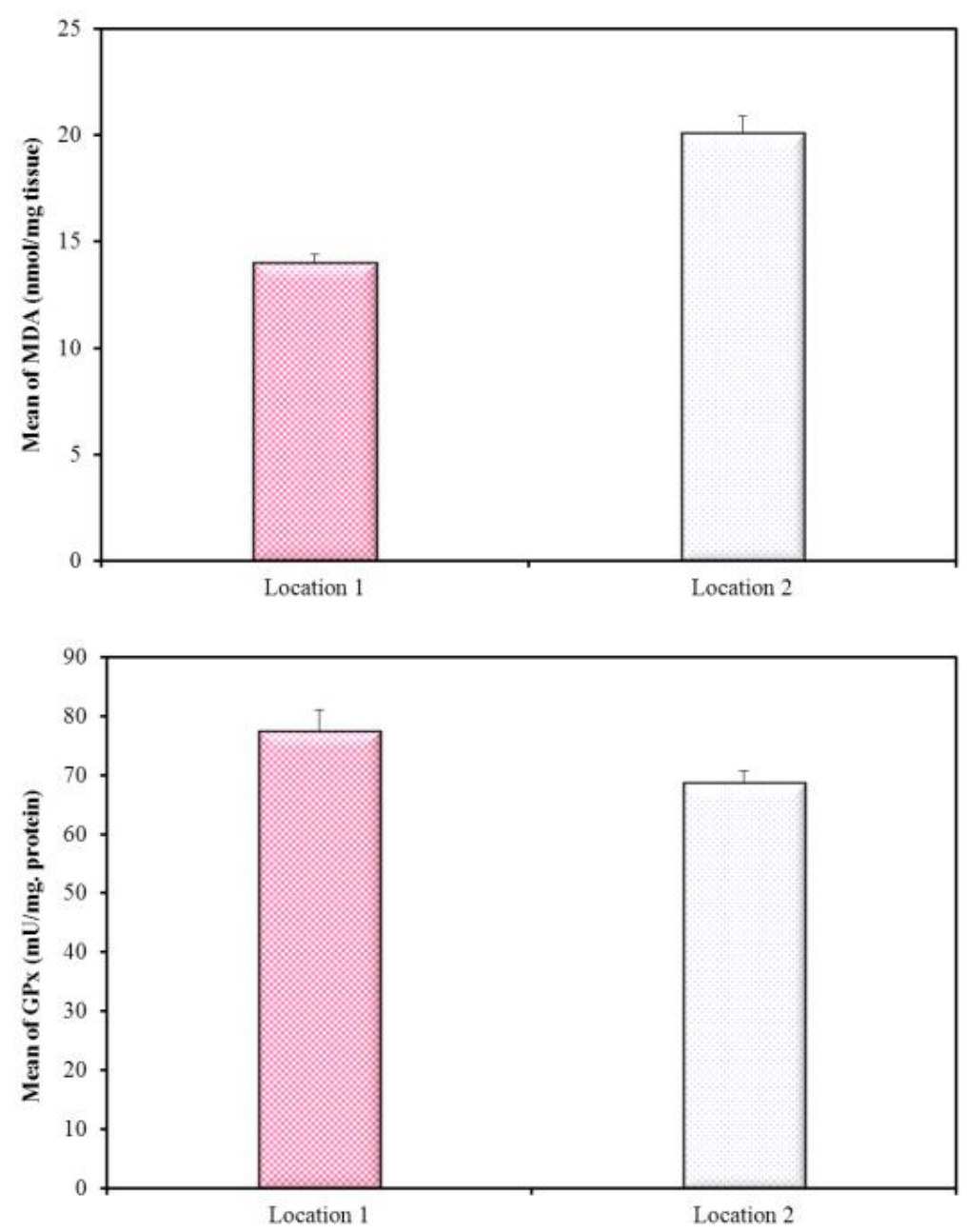

Fig. (6 a, b): Represents the mean concentration level of both GPx and MDA in insects collected from Lake Manzala, in Spring, 2018.

Table (5), fig.(6 a, b) shows the effects of heavy metals on the activity of the mean concentrations level of MDA in beetles tissues collected from Lake Manzala in spring, 2018. The data cited in the above table showed that the mean concentration level of MDA in loc.\#1 was $14.02(\mathrm{nmol} / \mathrm{mg}$ tissue), while it was $20.08(\mathrm{nmol} / \mathrm{mg}$ tissue) in that of loc.\#2 with a significant difference in concentration of MDA in the two locations. The data in a table (5) showed a significant decrease in GPx activity in beetles in loc.\#2 was 68.74 (mU/mg protein), while it was 77.4 in that of loc.\#1. The results of the present study showed that there was a significant decrease in GPx activity in samples collected from loc.\#2 compared with that of loc.\#1 telling that loc.\#2 is under stress of sewage pollution (Bahr El Baqur) drain. 
Table (7): $\quad$ Correlation between different parameters in Location 2

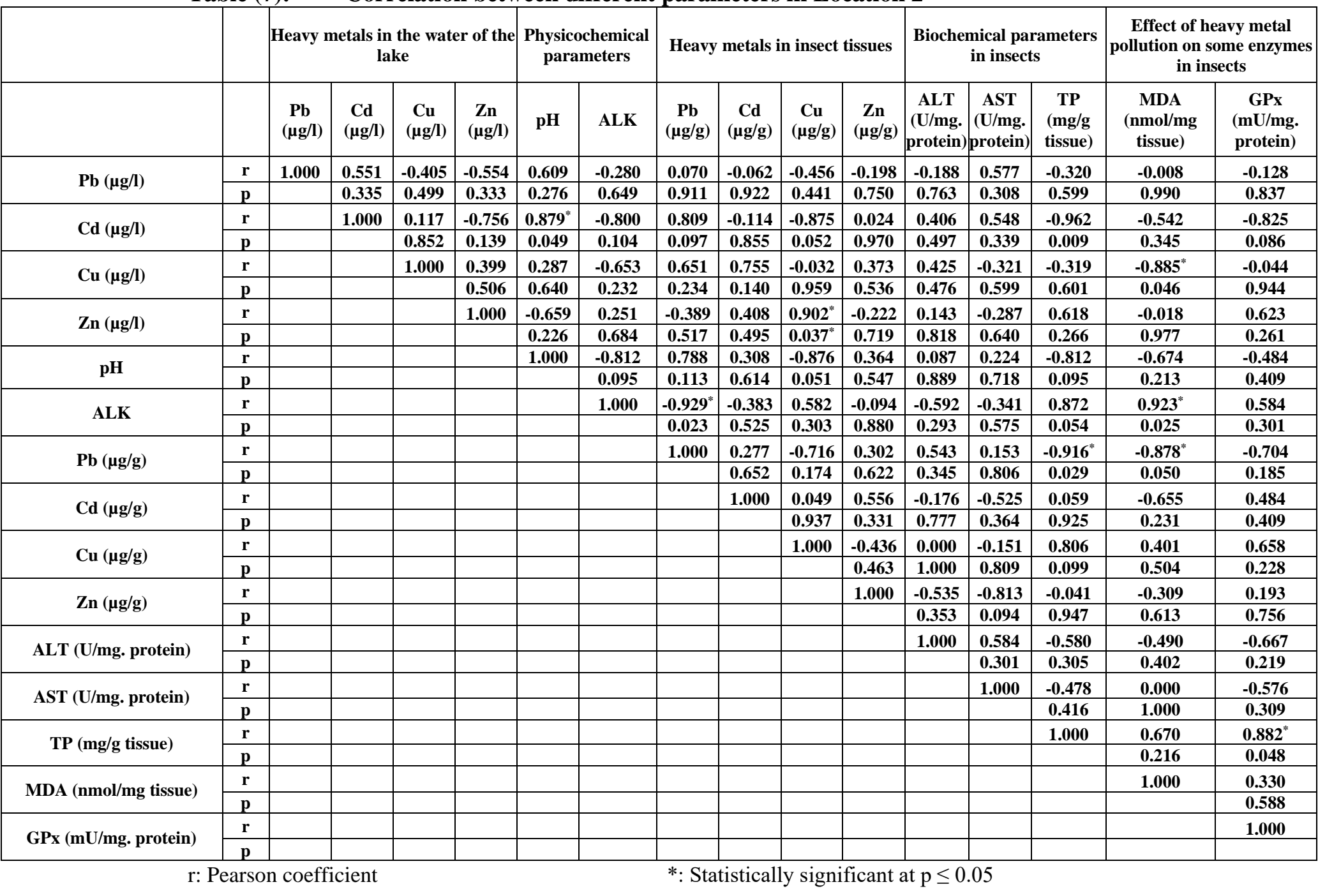

Table (7) represents the correlations that are found in loc.\#2 Lake Manzala. It is found here that $\mathrm{Pb}$ in water is positively correlated with $\mathrm{pH}$ and AST as $\mathrm{r}=$ 0.609 and $r=0.577$; respectively. $\mathrm{Cd}$ in water is negatively correlated with $\mathrm{Zn}$ in water, $\mathrm{ALK}, \mathrm{Cu}$ in insect tissues, TP, and GPx as $\mathrm{r}=-0.756, \mathrm{r}=-0.800, \mathrm{r}=-$ $0.875, \mathrm{r}=-0.962$, and $\mathrm{r}=-0.825$; respectively, while $\mathrm{Cd}$ in water is positively correlated with $\mathrm{pH}$ and $\mathrm{Pb}$ in insect tissues as $\mathrm{r}=0.879^{*}$ and $\mathrm{r}=0.809$; respectively. $\mathrm{Cu}$ in water in loc.\#2 is negatively correlated with ALK and MDA as $\mathrm{r}=-0.633$ and $\mathrm{r}=-$ $0.885^{*}$; respectively, whereas, $\mathrm{Cd}$ in water is positively correlated with $\mathrm{Pb}$ in insect tissues as $\mathrm{r}=0.755 . \mathrm{Zn}$ in water is negatively correlated with $\mathrm{pH}$ as $\mathrm{r}=-0.659$ while it is positively correlated with $\mathrm{Cu}$ 
in insect tissues, TP, and GPx as $\mathrm{r}=0.902 *, \mathrm{r}=0.618$, and $\mathrm{r}=0.623$; respectively.

The $\mathrm{pH}$ is positively correlated with $\mathrm{Pb}$ in insect tissues as $r=0.788$ whereas, it is negatively correlated with $\mathrm{ALK}, \mathrm{Cu}$ in insect tissues, TP, MDA as $\mathrm{r}=-$ $0.812, \quad \mathrm{r}=-0.876, \quad \mathrm{r}=-0.812$, and $\mathrm{r}=-0.674$; respectively. ALK is highly negatively correlated with $\mathrm{Pb}$ in insect tissues as $\mathrm{r}=-0.9 .29$ and with ALT as $r=-0.592$, whereas, it is positively correlated with $\mathrm{Cu}$ in insect tissues, TP, MDA, and GPx as $\mathrm{r}=0.582, \mathrm{r}=0.872, \quad \mathrm{r}=0.923^{*} \quad$ and $\mathrm{r}=0.584$; respectively. $\mathrm{Pb}$ in insect tissues is negatively correlated with $\mathrm{Cu}$ in insect tissues, TP, MDA, and GPx as $\mathrm{r}=-0.716, \mathrm{r}=-0.916^{*}, \mathrm{r}=-0.878^{*}$, and $\mathrm{r}=-$ 0.704 ; respectively. Cd in insect tissues is negatively correlated with MDA as $\mathrm{r}=-0.655$. $\mathrm{Cu}$ in insect tissues is positively correlated with TP and GPx as $r=0.806$ and $r=0.658$; respectively. $\mathrm{Zn}$ in insect tissues is negatively correlated with AST as $r=-$ 0.813 . ALT is positively correlated with AST as $\mathrm{r}=0.584$ and negatively correlated with TP and GPx as $\mathrm{r}=-0.580$ and $\mathrm{r}=-0.667$; respectively. AST is negatively correlated with GPx as $\mathrm{r}=-0.576$. TP is negatively correlated with MDA and GPx as $\mathrm{r}=0.670$ and $\mathrm{r}=0.882^{*}$; respectively. MDA is positively correlated with GPx as $\mathrm{r}=0.588$.

\section{Discussion:}

The poisonous synthetic compounds released into water get into natural pecking order from the earth, causing wellbeing anomalies ( $\mathrm{Li}$ and Kong, 2009). The satisfactory furthest reaches of Lead, Cadmium, Copper, Zinc ought not to surpass $(0.05,0.01,1,5$ $\mathrm{mg} / \mathrm{L}$; individually) for the ordinary nearness implies focuses in water as indicated by USEPA (2005). The portrayal of the physiological trustworthiness needs biomarkers of introduction to natural stressors. Biomarkers can be characterized as quantifiable adjustments at the physiological levels (Lionetto et al., 2003). The human effect has been incredibly changed over from a profitable lake to eutrophicate bowls (Hamza, 1999).

The results showed that the water of the two locations Lake Manzala were on the alkaline side, but there was a decrease in $\mathrm{pH}$ value in loc.\#2 (Eastern side of the lake) as the wastewater effluents are flowing into Manzala Lake from nine drains (Elmorsi et al., 2017). The $\mathrm{pH}$ value is affected by the sewage discharges (Nessim et al., 2005). The $\mathrm{pH}$ value is a significant factor in limiting the threshold concentration (Abou Taleb et al., 2004). The present study revealed low alkalinity in the studied locations and that Manzala Lake is not heavy polluted although that, Manzala Lake is suffering from environmental changes (Elmorsi et al., 2017), it is known that the water far away from pollution had low alkalinity (El Rais and El Sabrouti, 1994). Aquatic insects have been utilized as bio-indicators of pollution (Maron and Monteiro, 2002; Nummelin and Lodenius, 2007).

In the present study, the results showed that the mean $\mathrm{Pb}$ concentration in beetle tissue collected from Lake Manzala ranged from $(0.06-0.12 \mu \mathrm{g} / \mathrm{g})$, this is because of the ability of insects to accumulate heavy metals in their tissue. Cd means concentration level in beetles' tissue in the water of Manzala was reported as $0.03 \mu \mathrm{g} / \mathrm{g}$ in both locations. Cadmium may accumulate in aquatic tissues and affect their physiological functions (Sehar et al., 2014). Cd leads to a gradual extinction of the aquatic organisms in polluted waters (Sridhara et al., 2008; Radwan et al., 2012; Radwan et al., 2014; Radwan, 2016; Radwan et al., 2016; Radwan et al., 2017; Radwan et al., 2018). Cadmium pollution has elevated for decades due to industrial, agricultural, and municipal wastes (Ursinova and Hladikova, 2000).

In the current study, $\mathrm{Cu}$ and $\mathrm{Zn}$ concentration in beetles from Lake Manzala ranged from (0.2$0.1 \mu \mathrm{g} / \mathrm{g}, 0.07-0.09)$; respectively. The antioxidant systems have great potential to indicate the cellular responses to heavy metals (Cirillo and Cocchieri, 2012). In the current study, the obtained results showed a significant increase in MDA concentration in insects' tissues in Lake Manzala (loc.\#2, 20.08 $\mathrm{nmol} / \mathrm{mg}$ tissue). The generation of ROS is restrained by the cancer prevention agent chemicals action. The generation of AST and ALT is because of the quality of amino corrosive for the procedure of gluconeogenesis (Stohs and Bagchi, 2001; Migula and Laszczyca, 2004). Sewage prompts increment in the action of both AST and ALT (El Demerdash and Yousef, 2004; Amin and Hashem, 2012). The obtained result in the current study showed a significant decrease in protein content in insects' tissues in Lake Manzala (loc.\#2, $4.02 \mathrm{mg} / \mathrm{g}$ tissue).

The diminishing in protein content is because of the breakdown of protein into amino acids (Bizhannia et al., 2005; Li et al., 2012). Contamination stress can diminish the measure of aggregate protein substance of bugs (Bream, 2003; El barky et al., 2008). Cancer prevention agent compounds are imperative parameters for testing water for the toxicant's nearness. In the present study, the results showed a significant decrease in 
GPx activity in beetles' tissues in Lake Manzala (loc.\#2, $68.74 \mathrm{mu} / \mathrm{mg}$ protein). The decrease of the total protein may mirror the reduction in the enzymatic exercises of GPx.The diminishing in protein substance could be because of the breakdown of protein into amino acids (Yan et al., 2007). It is deduced in the present examination that creepy crawlies could be utilized as bio-pointers of oceanic contamination and that, the water nature of Lake Manzala is inside the standard water quality criteria for the freshwater (USEPA, 2005) except for Cd. It is incorporated from the gotten information that the eastern piece of the lake is greatly influenced by the swage contamination than the western piece of the lake Manzala. The end in the present examination that, the $\mathrm{pH}$ estimation of water the lake was soluble which comes in concurrence with (Elmorsi et al., 2017) on their work in Manzala Lake.

\section{References:}

Abdo MH (2004). Distribution of some chemical elements in the recent sediments of Damietta Branch, River Nile, Egypt. J Egypt Acad Soc Environ Dev. 5(2), 125-146.

Abou Taleb AE, Akel MM, Nessim RB and Ramadan MH (2004). Assessment of some heavy metals and their accumulation in Marine Organisms in Alexandria Coastal Environment, Master thesis, High Institute of Public Health, Alexandria University. p. 260.

Ahmed MH, El Lithy BM, Thompson JR, Flower RJ, Ramdani M, Ayache F and Hassan S (2009). Applications of remote sensing to site characterization and environmental change analysis of North African coastal lagoons. Hydrobiologia, 622,147-171.

Al-Yousuf M and El-Shahawi M (2000). Trace metals in liver, skin and muscle of Lethrinus lentjan fish species in relation to body length and sex. Sci. Total Environ.; 256(2): 87-94.

American Public Health Association (APHA). (1975). Standard methods for the examination of water and wastewater. 14th ed. New York, Washington: APHA: 1193.

American Public Health Association (APHA). (1999).Standard methods for examination of water and wastewater $\left(20^{\text {th }} \quad\right.$ ed). Washington: AWWA/WPCE. American Water Works Association, Water Environment Federation.
Amin KA and Hashem KS (2012). Deltamethrininduced oxidative stress and biochemical changes in tissues and blood of catfish (Clarias gariepinus): antioxidant defense and role of alpha-tocopherol. BMC Vet. Res.; 8-45.

Anonymous (2008). Ecology and Fisheries of Lake Manzala. Report of National Institute of Oceanography and Fisheries, Final Report, 108 pp.

Ayangbenro AS and Babalola OO (2017). A New Strategy for Heavy Metal Polluted Environments: A Review of Microbial biosorbents. Int. J. Environ. Res. Public Health, 14(1), 94.

Bahnasawy M and Khidr AND (2011). Assessment of heavy metal concentrations in water, plankton, and fish of Lake Manzala, Egypt. Turk. J. Zool.; 35 (2): $271-280$.

Bailey N (1981). Statistical Methods in Biology. Hodder and Stoughton, London.

Balke, M. (2005) Dytiscidae Leach, 1915. In: Kristensen, N.P. \& Beutel, R.G. (Eds.), Handbook of Zoology. Vol. IV. Arthropoda: Insecta. Part 38. Coleoptera. Vol. 1. Morphology and Systematics (Archostemata, Adephaga, Myxophaga, Polyphaga partim).Walter De Gruyter, Berlin, New York, pp. 90-116.

Bijita B, Priti G, Dharitri C, Arpita D, and Susmita $\mathrm{G}$ (2014). Bio-monitoring in lentic ecosystems of Irongmara, District Cachar, Assam, India, with special reference to aquatic insect community. Int. Res. J. Environ. Sci.; 3, 26-35.

Bisthoven D and Janssens L (1998). Sublethal parameters in morphologically deformed Chironomus larvae: clues to understanding their bioindicator value. Freshwater Biol.; 39(1), 179-191.

Bizhannia AR, Etebari K and Sorati R (2005). The effects of juvenile hormone analogue, Admiral, application on protein metabolism of silkworm larvae. Iran J Entomol Soc, 25: 43-56.

Bream AS (2003). Laboratory evaluation of heavy metals stress on certain biochemical parameters of the aquatic insect, Sphaerodema urinator Duf. (Hemiptera: Belostomatidae). Commun. Agric. Appl. Biol. Sci.; 68: 291-297.

Cadenas E (2004). Mitochondrial free radical production and cell signaling. Mol. Aspects Med.; 25(1), 17-26. 
Chaturvedi AD, Pal D, Penta S and Kumar A (2013). Ecotoxic heavy metals transformation by bacteria and fungi in aquatic ecosystem. World J. Microbiol. Biotechnol, 31, 1595-1603.

Chapman D (1996). Water Quality Assessments-A Guide to use of Biology, sediments, and water in Environmental monitoring- $2^{\text {nd }} \mathrm{edn}$, United Nations Educational, Scientific and Cultural Organization World Health Organization United Nations Environmental Programme E and FN Spon, Chapman and Hall, Cambridge Great Britain.

Cheung C and Zheng G (2001). Relationships between tissue concentrations of polycyclic aromatic hydrocarbons and anti-oxidative responses of marine mussels, Perna viridis. Aquat. Toxicol.; 52(3), 189-203.

Cirillo T and Cocchieri RA (2012). Cadmium accumulation and antioxidant responses in Sparus aurata exposed to waterborne cadmium. Arch. Environ. Contam. Toxicol.; 62(1):118-126.

Crowson RA (1981). The biology of the Coleoptera. London: Acad Press.

Czeczot H and Scibior D (2006). Glutathione and GSH-dependent enzymes in patients with liver cirrhosis and hepatocellular carcinoma. Acta Biochim. Pol.; 53(1): 237.

Dakkak A (2016). Egypt's Water Crisis - Recipe for Disaster. Middle East, Water. Available from: http://www.Ecomena.org/egypt-water. [Accessed on: May, 2017]

Dalton TP and Shertzer HG (1999). Regulation of gene expression by reactive oxygen. Ann. Rev. Pharmacol. Toxicol.; 39(1), 67-101.

Dar SA, Yousuf AR, Balkhi MH, Ganai FA and Ali MN (2014). Oxidative stress in the freshwater cyprinid crucian carp (Carassius carassius L.) upon chronic exposure to endosulfan. Toxicol. Environ. Chem.; 96(6), 906-916.

Easa A and Abou-Rayan A (2010). Domestic wastewater effect on the pollution of the groundwater in rural areas in Egypt. Fourteenth International Water Technology Conference, IWTC 14, Cairo, Egypt. p.909-923.

El-barky NM, Dahi HF and El-Sayed YA (2008). Toxicological evaluation and biochemical impacts for radient as a new generation of spinosyn of
Spodoptera littoralis (Boisd.), larvae. Egypt. Acad. J. Biolog. Sci.; 1: 85-97.

El-Demerdash FM and Yousef MI (2004). Cadmium-induced changes in lipid peroxidation, blood hematology, biochemical parameters and semen quality of male rats: protective role of vitamin $E$ and $\beta$-carotene. Food Chem. Toxicol.; 42(10): 1563-1571.

El Morsi RR, Mohamed A Hamed and Kh S Abou El Sherbini (2017). Physicochemical properties of Manzala lake, Egypt. Egypt. J. Chem vol 60, No 4, pp519-535.

Elstner E (1991). Oxygen radicals-biochemical basis for their efficacy. J. Mol. Med.; 69(21), 949956.

El-Said S and Kenawy M (1983). Geographical distribution of mosquitoes in Egypt. Journal of the Egyptian Public Health Association, 8 (1-2): 46-76.

Esterbauer H and Cheeseman KH (1990). Determination of aldehydic lipid peroxidation products: Malonaldehyde and 4-hydroxynonenal. Methods Enzymol, 186, 407-421.

El-Rayis O and El-Sabrouti M (1994). Some hydrochemical observation from Lake Mariut prior to diversion of sewage of eastern districts of Alexandria. Proc. 1st. Arab. Conf. Mar. Environ. Protec. (AMTA): 205-219.

El-Sabrouti MA (1990). Texture Chemistry and Mineralogy of the bottom sediments of Lake Manzala, Egypt. Bulletin of Faculty of Science, Alexandria University, 30(A): 296-320.

Fahmy GH (2012). Malathion toxicity: Effect on some metabolic activities in Oreochromis niloticus, the Tilapia fish. Int. J. Biosci. Biochem. Bioinform.; 2, 52-55.

GAFRD (2015).General Authority for fishery Resources Development, Food, and Fish, Cairo, Egypt.

Gaur N, Flora G and Yadav M (2014). A review with recent advancements onbioremediation-based abolition of heavy metals. Environ. Sci. Process. Imp, 16, 180-193.

Giera M and Ioan-Facsinay A (2012). Lipid and lipid mediator profiling of human synovial fluid in rheumatoid arthritis patients by means of $\mathrm{LC}_{-}$ 
MS/MS. Biochim. Biophys. Acta.; 1821(11): 14151424.

Gray CW, McLaren RG, Roberts AH and Condron LM (1999). Effect of soil pH on cadmium Phytoavailability in some New Zealand soils. N.Z. J. Crop Hort. Sci.; 27, 169-179.

Goyer R and Clarkson TW (2001). Toxic Effects of Metals. In: Klaassen CD (ed). Casarett and Doull's toxicology the basic science of poisons. 6th ed. New York: McGraw-Hill. p.811-868.

Hamza W (1999). Differentiation in phytoplankton communities of Lake Mariut: A consequence of human impact. Bull. Fac. Sci. Alex. Univ.; 39(1-2): 159-168.

Hansen M (1999). World Catalogue of Insects. Hydrophiloidea (Coleoptera). Aps. Stenstrup, Apollo Books, Copenhagen. 2; 416.

Hollmann F and Arends IW (2011). Enzymemediated oxidations for the chemist. Green Chem.; 13(2): 226-265.

Incekara U and Abdullah M (2003). A new record for the Turkish fauna: Cercyon ustulatus (Preyssler, 1790) (Coleoptera, Hydrophilidae). Turkish J. Entomol.; 27(2-10).

Jäch, M.A. (1995) Hydraenidae (Coleoptera). In: Jäch, M.A. \& Ji, L. (Eds.), Water Beetles of China. Vol. I. ZoologischBotanische Gesellschaft in Österreich and Wiener Coleopterologenverein, Wien, pp. 173-180.

Klaunig JE and Kamendulis LM (2004). The role of oxidative stress in carcinogenesis. Annu. Rev. Pharmacol. Toxicol.; 44, 239-267.

Lesilie E, Geoffrey I and James M (1991). Statistical analysis. In: Daly, L. and Bourke, J.G. (eds). Interpretation and uses of medical statistics. 4th ed. Oxford: Scientific Publications: 411.

Li W and Kong AN (2009). Molecular mechanisms of Nrf2-mediated antioxidant response. Mol.; Carcinog.; 48(2), 91-104.

Li B, Xie Y, Cheng Z, Cheng J, Hu R, Sang X, Gui S, Sun Q, Gong X, Cui Y, Shen W and Hong F (2012). Cerium chloride improves protein and carbohydrate metabolism of fifth-instar larvae of Bombyx mori under phoxim toxicity. Biol Trace Elem Res, 150: 214-20.
Lionetto MG, Caricato R, Giordano ME, Pascariello MF, Marinosci L and Schettino T (2003). Integrated use of biomarkers (acetylcholinesterase and antioxidant enzymes activities) in Mytilus galloprovincialis and Mullus barbatusin an Italian coastal marine area. Mar. Pollut. Bull.; 46, 324-330.

Lopes CT and Vasconcelos HL (2008). Evaluation of three methods for sampling ground-dwelling ants in the Brazilian Cerrado. Neotrop. Entomol.; 37(4), 399-405.

Loring, D.H. and Rantala, R.T. (1992): Manual for the geochemical analyses of marine sediments and suspended particulate matter. Earth. Sci. Rev.; 32, 235-283.

Lowry OH, Rosebrough NJ, Farr AL and Randall RJ (1951). Protein measurement with the Folin phenol reagent. J. Biol. Chem.; 193:265-275.

Lyras L and Cairns NJ (1997). An assessment of oxidative damage to proteins, lipids, and DNA in brain from patients with Alzheimer's disease. J. Neurochem.; 68(5), 2061-2069.

Mahler BJ and Van Metre PC (2006). Trends in metals in urban and reference lake sediments across the United States, 1970 to 2001. Environ. Toxicol. Chem.; 25(7), 1698-1709.

Mardzhanyan M (1997). Revision of the Hydrophilid Subfamily Sphaeridiinae (Coleptera, Hydrophilidae) in the Fauna of Armenia. Entomol. Rev.; 77(4), 423-438.

Marr JCA, Lipton J, Cacela D, Hansen JA, Meyer JS and Bergman HL (1999). Bioavailability and acute toxicity of Copper to rainbow trout (Oncorhychus mykiss) in the presence of organic acids simulating natural dissolved organic carbon. Can. J. Fish. Aquat. Sci.; 56:1471-1483.

Mazon A and Monteiro E (2002). Hematological and physiological changes induced by short-term exposure to copper in the freshwater fish, Prochilodus scrofa. Braz. J. Biol.; 62(4A):621-631.

Mehanna S F (2009). Growth, Mortality and Spawning Stock Biomass of striped red mullet Mullus surmuletus, in the Egyptian Mediterranean waters. Med. Mar. Sci.; 10 (2): 5-17.

Migula P and Laszczyca P (2004). Anti-oxidative defense enzymes in beetles from a metal pollution gradient. Biologia-Bratislava, 59(5):645-654. 
Miller DM, Buettner GR and Aust SD (1990). Transition metals as catalysts of "autoxidation" reactions. Free Radic. Biol. Med.; 8, 95-108.

Mukhopadhyay S and Hashim M (2011). Remediation technologies for heavy metal contaminated groundwater. J. Environ. Manage.; 92(10), 2355-2388.

Nicholsa LE, Spectora T, Davise S, Escobarc AL, Favilad F, Vulinece M and Global K (2007). Dung beetle response to tropical forest modification and fragmentation: A quantitative literature review and meta-analysis. Biologic Conserve, 137, 1-19.

Nummelin M and Lodenius M (2007). Predatory insects as bio-indicators of heavy metal pollution. Environ. Pollut, 145(1): 339-347.

Ohe T, Watanabe T and Wakabayashi K (2004): Mutagens in surface waters: a review Mutat Res, 567: 109-149.

Ohkawa K, Ohishi W and Yagi KA (1979). Assay for lipid peroxides in animal tissues by thiobarbituric acid reaction. Biochem, 95:351-358.

Paglia DE and Valentine WN (1967). Studies on the quantitative and qualitative characterization of erythrocytes peroxidase. J. Lab. Clin. Med.; 70, 15869.

Pryor WA (1989). On the detection of lipid hydroperoxides in biological samples. Free Radical Biol. Med.; 7(2), 177-178.

Puri BK (2002). SPSS in practice: an illustrated guide. London: Arnold. 320 pp.

Rasmussen LD and Sørensen SJ (2000). Application of a merlux biosensor for estimating bioavailable mercury in soil. Soil Biol. Biochem.; 32(5), 639-646.

Riley JP and Taylor D (1968). Chelating resin for concentration of the trace elements from the water and their analytical use in conjunction with atomic absorption spectrometry. Anal. Chemis. Acta.; 40, $479-485$.

Sa'eed MD and Mahmoud AM (2014). Determination of Some Physicochemical Parameters and Some Heavy Metals in Boreholes from Fagge L.G.A of Kano Metropholis Kano State- Nigeria. World. b J. Analyt. Chem. 2. (2): 42-46.

Safari Z, Naderi S and Ghasemi Z (2014). Examine the role of education in reducin environmental pollution. Indian J. of Fundamental and Applied Life Sciences, 4(S1), 1178-1183.

Schafer FQ and Buettner GR (2001). Redox environment of the cell as viewed through the redox state of the glutathione disulfide/glutathione couple. Free Radic. Biol. Med.; 30(11), 1191-1212.

Sehar A, Shafaqat A, Uzma Sh A, Mujahid F, Saima AB, Fakhir H and Rehan A (2014). Effect of Different Heavy Metal Pollution on Fish. Res J. Chem. Environ. Sci.; 2:35-40.

Shahid M, Pourrut B, Dumat C and Nadeem M (2014). Heavy-metal-induced reactive oxygen species: phytotoxicity and physicochemical changes in plants. Rev. Environ. Contam. Toxicol, 232,1-44.

Short AEZ and Heabuer F (2006). World Catalogue of Hydrophiloide-Additions and Corrections, I. (1999-2005) (Coleoptera). Koleopterologische Rundschau, 76, 315-359.

Sildanchandra W and Crane M (2000). Influence of sexual dimorphism in Chironomus riparius Meigen on toxic effects of cadmium. Environ. Toxicol. Chem.; 19(9), 2309-2313.

Song SB, Xu Y and Zhou BS (2006). Effects of hexachlorobenzene on antioxidant status of liver and brain of common carp (Cyprinus carpio). Chemosphere, 65, 699-706.

Stadtman ER (2004). Cyclic oxidation and reduction of methionine residues of proteins in antioxidant defense and cellular regulation. Arch. Biochem. Biophys.; 423(1), 2-5.

Stéphane A, Jörg S, Gérard B and Jouanneau JM (2004). Fifty-year sedimentary record of heavy metal pollution $(\mathrm{Cd}, \mathrm{Zn}, \mathrm{Cu}, \mathrm{Pb})$ the Lot River reservoirs (France). Environ Pollut, 132, 413-426.

Sridhara CN, Kamala C, Samuel S and Raj D (2008). Assessing risk of heavy metals from consuming food grown on sewage irrigated soils and food chain transfer. Ecotoxicol. Environ. Saf, 69:513-524.

Stohs SJ and Bagchi D (2001). Oxidative mechanisms in the toxicity of chromium and cadmium ions. J. Environ. Pathol. Toxicol. Oncol, 19(3): 201-213.

Thevenon F, Graham ND, Chiaradia M, Arpagaus P, Wildi W and Pote J (2011). Local to regional-scale industrial heavy metal pollution recorded in sediments of large freshwater lakes in central Europe 
(lakes Geneva and Lucerne) over the last centuries. Sci. Total. Environ.; 412-413, 239-247.

Tietz NW(1976). Fundamentals of clinical chemistry. Philadelphia: Wound B Saunders Co: 924-929.

Tylianakis J, Veddeler D, Lozada T, Lopez RM, Benítez P, Klein AM and Onore G (2004). Biodiversity of land-use systems in coastal Ecuador and bio-indication using trap-nesting bees, wasps, and their natural enemies. Lyonia, 6(2), 7-15.

USEPA, 2005: United States Environmental Protection Agency) (2005): Current National Recommended Water Quality Criteria. Fact Sheet (May 25, 2005).

United States Environmental Protection Agency (USEPA). (2001). The quality of our nation's water: executive summary of the national water quality inventory: report. Washington, DC, USA: Congress, Office of Water. p 209.
Ursinova M and Hladikova V (2000). Cadmium in the Environment of Central Europe. In: Markert, B. and Friese, K. (Eds.). Trace Metals in the Environment. Netherlands: Elsevier, 87-107.

Valko M and Leibfritz D (2007). Free radicals and antioxidants in normal physiological functions and human disease. Int. J. Bioch. Cell Biol.; 39(1): 4484.

Valko M, Rhodes CJ, Monocol J and IzakovicMazur M (2006). Free radicals, metals and antioxidants in oxidative stress-induced cancer. Chem. Biol. Interac.; 160, 1-40.

Viarengo A (2003). Mechanisms of regulation and toxicity at the cellular level heavy metals marine invertebrates. Rev. Aquat. Sci.; 1, 295-317.

Yan B, Wang L, Li Y, Liu N and Wang Q (2007). Effects of cadmium on hepatopancreatic antioxidant enzyme activity in a freshwater crab Sinopotamon yangtsekiense. Acta Zool Sin, 53: 1121-8. 